\title{
Generation Z Career Identity Formation Through Guidance and Counselling Services
}

\author{
Arni Nur Laila ${ }^{1^{*}}$, Monica Widyaswari ${ }^{2}$ \\ ${ }^{1}$ Universitas Pendidikan Indonesia, ${ }^{2}$ Universitas Negeri Surabaya \\ *Corresponding author, e-mail: arninurlaila@upi.edu
}

Received August 02, 2021; Revised August 31, 2021; Accepted Sept. 20, 2021; Published Online 2021-10-01

\section{Conflict of Interest} Disclosures:

The authors declare that they have no significant competing financial, professional or personal interests that might have influenced the performance or presentation of the work described in this manuscript.

\begin{abstract}
This study aims to describe a generation $\mathrm{Z}$ career identity formation through guidance and counselling services. This research used a qualitative phenomenology approach. The research subjects are two people, late adult adolescents (18-25 years), based on their late teens tended to require counselling and guidance services and began to consider future careers. Data collection methods used in-depth interviews and observation. This research results from career identity, determining interests, having confidence in the career to be pursued, and ownership of figures to explore the chosen career field. Generation $\mathrm{Z}$ career identity includes the embodiment of self-concept for the chosen job. The digitalization era also influences generation Z's career identity formation. Therefore, the role of guidance and counselling services is crucial in helping individual planning and specialization. The study recommends that Generation $\mathrm{Z}$ must plan for their future career. This can be obtained from social support, including guidance and counseling services.
\end{abstract}

Keywords: career identity, generation Z, guidance and counselling services.

\section{Introduction}

Every human being slowly and unconsciously moves to find his identity. Self-identity is an identity that concerns the subject's quality of existence, which means that the subject has a unique personality (Tsang, Hui, \& Law, 2012). A person finds Self-identity in different ways according to the uniqueness of the self. Self-identity is an awareness of the person from observation and assessment, synthesising all aspects of the self and becoming a unified whole. A person's self-identity is formed gradually and is also interpreted in different ways and meanings. 
Self-identity begins to be dug into truth by individuals since their teens (Barnett, 2019). Identity formation involves synthesizing of skills, beliefs, and identification into a more or less coherent and unique whole with a sense of continuity with the past and future direction (Marcia, 1993). Simply put, identity as structure refers to how experiences are handled and what experiences are considered essential. One part of the formation of self-identity is one's career identity. Career identity becomes an ongoing part of every individual's journey to find potential and enjoy work in life.

Building a career identity is one of the most central aspects of the transitional life of a teenager to an adult (Porfeli, Lee, Vondracek, \& Weigold, 2011). Career identity is an essential measure of a career in an individual's personality. There is work involvement and a desire for upward mobility by finding career satisfaction in life (Nazar \& Heijden, 2012). Career identity is a crucial aspect of one's life journey. Career identity is a meaning that has been sought from adolescence to adulthood in planning a career and carrying out his profession. Life satisfaction in carrying out work grows from understanding and interpreting the career identity they have.

In addition, career identity is also assessed as a structure of meaning for individuals to connect their motivation, interests, and competencies with the accepted career role (Xu \& Lee, 2019). Career identity shows how a person positions himself with roles that shape himself as a process of positive self-esteem journey (Hamilton \& Marcinkus, 2011). Career identity shows how a person positions himself with roles that shape himself as a process of positive self-esteem journey (Hamilton \& Marcinkus, 2011). Career narrative has an essential role in one's career identity, which describes the journey and career meaning for oneself (Meijers \& Lengelle, 2012). Career identity defines themselves in professional roles with a constellation of relatively stable, enduring beliefs, values, and experiences (Weber \& Ladkin, 2011).

One indicator of career identity is the desired career following the current reality of goals, desires, and opinions (Felder, 2014). An individual's career has rapid development when he has a suitable container. Careers that match passion are easier to develop, and individuals have their comfort when running to increase productivity with perfect results. Thus, career identity leads to the meaning of the individual by his character.

Generation $\mathrm{Z}$ characters are known as gadget native and hyperconnected. They are the first generation to access a wide scale of digital communication technology, unlike Gen $Y$, who primarily communicates with texts, Gen Z, with the technology advancement that enables social interchange. These characters also form Generation $Z$, who are more confident and want to guarantee their future. They know that a career has a vital role in making their dreams come true. This generation has a high degree of independence and dislikes authority (Barhate \& Dirani, 2021). This is as the News Northeastern Survey (2014) results reveal that this generation $\mathrm{Z}$ has more ability to meet their personal needs without relying on others. Such a character makes up $42 \%$ of Generation $Z$ who choose to have a career with their strengths. Thus, Generation $Z$ is more independent. However, to start a career, Generation $\mathrm{Z}$ focuses on independence alone and the technological sophistication that they must master as the times progress.

Based on the explanation above, it is essential to research career identity for Generation $Z$. The purpose of this study is to describe the formation of career identity for Generation $Z$ through guidance and counselling services. This study focused on adolescents who are still in college with an age range of 18-25 years. This is determined by considering that adolescents in that phase have begun to consider their future careers. This is also following the explanation that states that one of the most crucial age ranges in career development are 18-25 years. In this age range, the decisions taken will significantly impact one's career (Mansyur, Chairunnisa, \& Hidayat, 2020). On the other hand, few teenagers can still identify their careers and need counselling and guidance services to support their careers. Therefore, the results also serve as a guide in providing guidance and counselling services in education.

\section{Method}

\section{Research Design}

The type of approach used in this study is a qualitative approach with phenomenological research methods, namely research that describes or makes a systematic description of the facts in this study. The qualitative approach emphasizes human behavior with conditions that are as they are, prioritizing the individual who becomes the informant and searching for data sources to obtain in-depth and meaningful information. In this study used a qualitative approach with this phenomenology research method, the 
researcher pays attention to and explores information from the subjects in order to gain awareness about their experiences in certain events, which are then adapted to the research objectives, namely describing the meaning of Generation $\mathrm{Z}$ on their identity which can be supported by guidance and counselling services.

The primary data sources were late adult adolescents (18-25 years) with two subjects in this study. The selection of informants was based on several criteria, namely: the two informants including late teens based on their age, both of them were different backgrounds (family and environmental conditions), they were final year students at one of the universities which needed guidance and counseling services and needed to consider future careers. According to Moleong (2011), the primary data sources in qualitative research are narratives and actions. The rest are additional data, such as written data sources and documentation.

Data collection techniques used in this study include:

a) In-depth interview

This in-depth interview method was used to conduct informants to collect data on (1) the meaning of Generation Z on their identity; (2) Generation Z defines career identity; and (3) the condition of the spiritual identity of generation $Z$. In-depth interviews were conducted based on the life history of each informant. Life history is an option to remember in this way. It can reveal the subject's life history thoroughly and in detail. Interviews were conducted in depth accompanied by observations.

\section{b) Observation}

In this study, researchers used direct observation, namely direct observation based on the observation guidelines for the symptoms of the subjects studied. The subjects in question are late adult adolescents with a subject of two people. In addition, he made observations related to the habit patterns of each informant in interpreting his identity and career identity. Observations were carried out in places frequented by informants on campuses, boarding houses, and cafes. This research lasted for approximately three months in order to obtain in-depth data on each informant.

The data collection instrument used: (a) interview guidelines; (b) observation guidelines; (c) field notes (self-report) accompanied by a recording device. At the same time, the data analysis technique uses thematic analysis techniques. This analysis technique analyses meaning based on prominent themes and relates to the categories in the research objectives (Hanurawan, 2012). The stages of data analysis include (1) phenomenological reduction: a kind of abstraction to see something and cover other less relevant things; (2) editorial reduction: reducing phenomena seen from something general; and (3) transcendental reduction: reducing the phenomenal from the supra-individual perspective as an object for a general subject.

\section{Results and Discussion}

Data analysis is part of a series of how researchers analyze data found in the field. The data obtained in the field are then described by presenting the data. The next stage is to analyze the data from the field based on the theory used as reference material. The following is an explanation of the results related to the career identity of Generation $\mathrm{Z}$ based on the data analysis that has been carried out.

\section{Determination of Interest in Forming Career Identity}

Career decision making is an essential skill. Career decision making is explored through the identification process and information processing skills (Zamroni, 2016). A person's career journey has started since he was in the womb. Individuals interact with the career world starting from the family environment. This is also believed by the informant as follows:

I have been directed since childhood to focus on academic goals, achievement orientation and getting good grades (AZN/Mhs/W/20-1-18/K/RMD).

I like public speaking. On the other hand, I also want to be a memorizer of the Quran. It has been formed since childhood since the sixth grade. I started memorizing rote. Successfully memorized the letter Yasin, Al-Mulk, and other great letters. He already memorized juz amma in kindergarten because his family environment shaped him into a memorizer (FZI/Mhs/W/22-1-21/P/PKG).

In this case, it can be interpreted that one of the factors and a strong influence in forming the career identity of Generation $\mathrm{Z}$ is parents and the harmony of family relationships. They get the values of life starting from the family. This condition is by the statement which states that the first and foremost education 
is family. Family is everything to them. Values are born from the family environment (Andrea, B., Gabriella, H., \& Timea, 2016). Therefore, generation $\mathrm{Z}$ holds the values that the family has instilled until now.

The formation of career identity can then be influenced by environmental factors, not only by the family environment. In this case, it includes residence, peers, school, and society as a whole which becomes a single unit and is absorbed by a person in making choices that become potential and interests, including the development of technology and information as it is today. Like the two informants who are part of generation $Z$. They were born with the hustle and bustle and the rapid advancement of technology and the internet. Through this, it becomes one of the factors in the perspective and pattern of thinking and acting of digital natives in their daily lives and planning for the day ahead. They, as digital natives, do not just think locally and have an open interaction with anyone. It also brings generation $\mathrm{Z}$ to have foresight with various references that they see, learn and experience. The existence of this makes Generation $Z$ also faced with various difficulties in making decisions. This condition was also experienced by each of the informants in this study.

Before determining their interest in the career, they are pursuing, each informant also experiences doubts in determining the area of interest for his future career. In this case, guidance and counselling services are needed to assist direction so that they have confidence in career interests. This is information from the two informants who take advantage of both universities' guidance and counselling services. This is like implementing guidance and counselling programs for career services that are very much needed, which can provide direction regarding career decisions made by an individual. Of course, mature individuals will make career choices that are right for themselves by considering various aspects of themselves. However, on the other hand, it also helps shape individual personality maturity, especially generation Z. Considering that immature individuals are very likely to make mistakes in career decision making (Hidayat \& Prabowo, 2019).

Based on the results of the guidance and counselling services that provide direction related to career identification, each informant can determine his interest and prepare himself as a form of initial preparation as follows:

I have been a tutor since the fourth semester. I like to practice my knowledge for my purpose as a lecturer too. First, I intend to study. I did it so I could pass on what I got from campus. My passion is teaching. So far, I intend to seek knowledge (AZN/Mhs/W/9-1-21/K/MTV).

I became a memorizer of the Koran, and $M C$ is already a passion, and until now, I live it. The beginning of the trip was not income-oriented, so because I like and enjoy it. The most important thing for me is channelings talent. I am already happy until I finally start making a profit from my passion (FZI/Mhs/W/10-1-21/P/PSS).

Based on the information above, it can be interpreted that the informant, as generation $Z$, determines and explores the choice of career interests that suit him. The role of interest in one's career identification is significant. This is because as a guide, to be more focused in carrying out various tasks that are part of his career. Therefore, in making career decisions that are their interests, it is also interpreted as a complex process. It requires an understanding and an appropriate critical thinking process to be implemented (Arjanggi, 2017).

Thus, it can be concluded that one of the indicators of career identity is the desired career according to the interests, goals and desires that are appropriate (Stringer \& Kerpelman, 2010). An individual's career has rapid development when he has a suitable container. Careers that match passion are easier to develop, and individuals have their comfort when running, thereby increasing productivity with perfect results. In other words, in general, career identity also leads to the meaning of the individual according to him.

\section{Confidence in a Predetermined Career}

The manifestation of career identity is not only completed. The individual can determine interests or choices but is also manifested in the form of responsibility, with the hope of getting the maximum benefit from this choice (Zamroni, 2016). The existence of this responsibility is shaped by one of the principles of life. Every individual must own that, including generation Z. This principle is also a form of encouragement or belief in one's possessions. This is related to self-efficacy. Self-efficacy is related to one's self-confidence.

This is also supported by research findings from each of the informants who form beliefs for their careers through various habits such as (a) writing down their desired goals and sticking them in the corner of the room where they stay; (b) starting to get used to being brave and independent in doing the work defined as his career; (c) limit themselves from various activities that are less useful for career development; (d) pursue 
their passion patiently; and (e) discipline and high dedication. Through these simple habits, both what they get from intrinsic and extrinsic motivation, it is believed that everything that is expected to be part of their career can be achieved and obtain maximum results. Based on the findings of the study as the nature of belief or efficacy.

To solve problems in building the confidence of Generation $\mathrm{Z}$ to be able to face challenges and obstacles in the process of forming a career identity. One of the efforts to be done is through counselling guidance services with the RET (Rational Emotive Therapy) approach. In addition, preventive and curative efforts are carried out by inviting Generation $\mathrm{Z}$ to reason and eliminate irrational thoughts about themselves that can interfere with their self-efficacy (Nurfadhilla, 2020).

Beliefs or efficacy related to the habits of human life that are based on the principles of character, such as integrity, humility, loyalty, self-limitation, courage, justice, patience, diligence, simplicity, and decency, should be developed from within to the outside. Not by coercion from outside into humans. A person is influential if the individual can solve problems effectively, maximize opportunities, and continuously learn and integrate other principles in a growth spiral. Even self-efficacy is often called self-confidence (Berkowitz \& Bier, 2004; Lane, Lane, \& Kyprianou, 2004).

Self-confidence is the extent to which a person has confidence in assessing his abilities and the extent to which a person can feel the "appropriateness" to succeed in a predetermined career field. This confidence can be one of the principles that must be owned. Confidence in our abilities is obtained after interacting with others and getting feedback (Falk \& Kim, 2019). Self-efficacy is essential because self-efficacy reflects a person's belief that the person can overcome the problems at hand. The concept of individual efficacy derived from Bandura's theory can be applied in specific career domains and is not general, so this concept must refer to certain behaviors to be meaningful, one of which is individual behavior in career exploration, self-efficacy towards career decision making (Betz, Klein, \& Taylor, 1996; Gainor, 2006).

Thus, it can be concluded that self-confidence or self-efficacy towards choosing a field of interest in a psychology career can be assisted through guidance and counselling services. This belief describes a level of career development in which individuals have a precise level of career interests based on various considerations and commitments that are manifested in the form of habits accompanied by principles that have been firmly held to achieve their career choices. Through this belief, Generation $\mathrm{Z}$ has the fighting power in pursuing their careers.

\section{Figure or Role Model for Career Deepening}

As a form of career deepening efforts, the two informants in this study also learned from figures who were considered motivating or inspiring. To support the career identity process, the two informants got a figure in the family environment. The family environment shapes them to be consistent individuals to pursue their passion. This is like the role of the family, namely as the first role model for children (Hou, Wu, \& Liu, 2019; Jemini-Gashi, Duraku, \& Kelmendi, 2019; Sonnert, 2009). Apart from their parents, they also get a figure to be someone else. Figures outside the family environment are obtained from informal learning processes accessed through various social media such as LinkedIn, Instagram, and various YouTube channels that support the deepening of their careers. Such conditions are like the statement that social media support can help individuals improve and develop careers, especially in an era like today the role of technology and information cannot be separated from human life, especially generation Z (Roman, 2014; Sampson, Kettunen, \& Vuorinen, 2020).

The existence of a learning process through others who are assessed as role models. Role models under the theory developed by Bandura based on social learning theory. This theory emphasizes a reciprocal causal relationship between behavioral, environmental factors and interrelated personal factors. Modelling is a technique popularized by Albert Bandura. Modelling is the process by which individuals learn from watching other people. Modelling has also been referred to as imitation, identification, observational learning, and representative learning. Modelling can produce three types of responses. Namely, the client can acquire new behaviors patterns by watching others, called the observation of learning effects. Second, modelling can strengthen or weaken the client's behaviors after learning, which is called the inhibitory effect or the disinhibitory effect. Finally, model behaviors can serve as cues that signal the client to respond, called the response facilitation effect (Vignoli, 2015). In this case, through the theory, it can be interpreted that role models greatly influence career decisions. Furthermore, figures can also increase self-efficacy and provide legitimacy and encouragement to turn ambitions into reality. This means that individuals are attracted to 
role models who are perceived to be similar in terms of characteristics, behaviors' or goals (role aspects) and from whom they can learn specific abilities or skills (model aspects) (Sulistyowati \& Widyastuti, 2017).

When viewed from guidance and counselling services, role models are essential to support career success. Career success is caused by someone having a "good role model" and career failure by "lack of role model". Role models have the function of providing inspiration, increasing self-efficacy, learning and guidance, and support (Margahana, 2019; Sulistyowati \& Widyastuti, 2017). Individuals are urged to look for role models who can help them achieve their goals. The modelling approach can support decision making and plan in human behaviors, which plays an important role. Modelling is closely related to behaviors, and thinking patterns are directed at something more constructive by seeing and identifying the model that is a role model. The presence of the model carried out by the two informants is also expected to provide assistance and provide motivation for further self-development, especially those related to careers.

Thus, based on the description of the discussion above, it can generally be concluded that the career identity of Generation $\mathrm{Z}$ cannot be separated from the world of work they want and have carved out at this time. This is supported by research which states that work is the embodiment of self-concept, and individuals try to apply self-concept by choosing work as self-expression. This is also known as super career theory (Kraus, Chen, \& Keltner, 2011). Therefore, the work chosen by Generation Z is a form of self-expression. Not much different from the self-identity of Generation Z, which is full of ambition, optimism, and existence recognised by the general public (Bencsik, Juhász, \& Horváth-Csikós, 2016). Therefore, the career identity of Generation $\mathrm{Z}$ is a reflection of itself.

Generation Z's career identity works happily following their passion and must be manifested in the form of responsibility. However, generation Z's career identity is also influenced by the development of today's era with the advancement of technology and information, which also shapes them. Therefore, guidance and counselling services are crucial in providing individual planning services and specializations. The purpose of individual specialization and planning can be formulated to facilitate individuals in planning, monitoring, and managing their educational, career, and personal-social development plans (Athanasou \& Perera, 2019; Santoso, 2013). The importance of the counsellor's role in assisting counselees to be more planned and focused in developing passion and future careers in the scope of education and work.

\section{Conclusion}

Based on the research focus that has been determined, it is concluded that the career identity of Generation $\mathrm{Z}$ can be formed through guidance and counselling services. From the research findings, career identity formation begins with determining interests, having confidence in the career to be pursued, and ownership of figures to explore the chosen career field. Generation Z's career identity cannot be separated from the world of work they want and has carved out at this time. Generation Z's career identity includes the embodiment of the self-concept of the chosen job or one of their forms of self-expression. The formation of career identity is following the character of Generation Z, which is also influenced by the current digitalisation era.

Therefore, the role of guidance and counselling services is significant in helping individual planning and specialisation. The goal is to facilitate individuals in planning, monitoring, and managing plans for education, career, and personal-social development. The importance of the counsellor's role in assisting individuals, especially Generation Z, is to be more planned and focused on developing passion and future careers in education and work.

\section{Acknowledgement}

The authors acknowledge informants who willing to be research respondents, furthermore for Indonesia Endowment Fund for Education (LPDP) under the auspices of the Ministry of Finance of the Republic of Indonesia for research and publication funds. 


\section{References}

Andrea, B., Gabriella, H., \& Timea, J. (2016). Y dan Z Generations at Workplaces. Journal of Competitiveness., 8(3).

Arjanggi, R. (2017). Identifikasi Permasalahan Pengambilan Keputusan Karir Remaja. Psikologika: Jurnal $\begin{array}{llll}\text { Pemikiran dan } & \text { Penelitian } & \text { 22(2), } & \text { Psikologi, }\end{array}$ https://doi.org/10.20885/psikologika.vol22.iss2.art3

Athanasou, J. A., \& Perera, H. N. (Eds.). (2019). International Handbook of Career Guidance. Cham: Springer International Publishing. https://doi.org/10.1007/978-3-030-25153-6

Barhate, B., \& Dirani, K. M. (2021). Career aspirations of generation Z: A systematic literature review. European Journal of Training and Development, ahead-of-print(ahead-of-print). https://doi.org/10.1108/EJTD-07-2020-0124

Barnett, R. V. (2019). Helping Teens Answer the Question "Who Am I?": Cognitive Development in Adolescents. 2005(15), 3.

Bencsik, A., Juhász, T., \& Horváth-Csikós, G. (2016). Y and Z Generations at Workplaces. Journal of Competitiveness, 6(3), 90-106. https://doi.org/10.7441/joc.2016.03.06

Berkowitz, M. W., \& Bier, M. C. (2004). Research-Based Character Education. The ANNALS of the American Academy of Political and Social Science, 591(1), $72-85$. https://doi.org/10.1177/0002716203260082

Betz, N. E., Klein, K. L., \& Taylor, K. M. (1996). Evaluation of a Short Form of the Career Decision-Making Self-Efficacy Scale. Journal of Career Assessment, 4(1), 47-57. https://doi.org/10.1177/106907279600400103

Falk, R., \& Kim, S. S. (2019). The War System: An Interdisciplinary Approach. Routledge.

Gainor, K. A. (2006). Twenty-Five Years of Self-Efficacy in Career Assessment and Practice. Journal of Career Assessment, 14(1), 161-178. https://doi.org/10.1177/1069072705282435

Hamilton, V. E., \& Marcinkus, M. W. (2011). Married professional women's career exit: Integrating identity and social networks. Gender in Management: An International Journal, 26(1), 57-83. https://doi.org/10.1108/17542411111109318

Hanurawan, F. (2012). Metode Penelitian Kualitatif dalam Ilmu Psikologi. Surabya: KPKM Universitas Airlangga.

Hidayat, D. R., \& Prabowo, A. S. (2019, April). A Career Development Program for Higher Education in Indonesia; The Strategy to Achieve Career Maturity. 125-129. Atlantis Press. https://doi.org/10.2991/icamr-18.2019.32

Hou, C., Wu, Y., \& Liu, Z. (2019). Career decision-making self-efficacy mediates the effect of social support on career adaptability: A longitudinal study. Social Behavior and Personality: An International Journal, 47(5), 1-13. https://doi.org/10.2224/sbp.8157

Jemini-Gashi, L., Duraku, Z. H., \& Kelmendi, K. (2019). Associations between social support, career selfefficacy, and career indecision among youth. Current Psychology. https://doi.org/10.1007/s12144019-00402-X

Kraus, M. W., Chen, S., \& Keltner, D. (2011). The power to be me: Power elevates self-concept consistency and authenticity. Journal of Experimental Social Psychology, 47(5), 974-980. https://doi.org/10.1016/j.jesp.2011.03.017

Lane, J., Lane, A. M., \& Kyprianou, A. (2004). Self-Efficacy, Self-Esteem And Their Impact On Academic Performance. Social Behavior and Personality: An International Journal, 32(3), 247-256. https://doi.org/10.2224/sbp.2004.32.3.247

Mansyur, A. I., Chairunnisa, D., \& Hidayat, D. R. (2020). Implementasi Teori Super Pada Program Layanan Bimbingan Dan Konseling Karir Untuk Mahasiswa Perguruan Tinggi. Psikologi Konseling, 15(2). https://doi.org/10.24114/konseling.v15i2.16197

Marcia, J. E. (1993). The Ego Identity Status Approach to Ego Identity. In J. E. Marcia, A. S. Waterman, D. R. Matteson, S. L. Archer, \& J. L. Orlofsky (Eds.), Ego Identity: A Handbook for Psychosocial Research (pp. 3-21). New York, NY: Springer. https://doi.org/10.1007/978-1-4613-8330-7_1

Margahana, H. (2019). Self Efficacy, Self Personality And Self Confidence On Entrepreneurial Intention: Study On Young Enterprises. Journal of Entrepreneurship Education, 22(1), 13.

Meijers, F., \& Lengelle, R. (2012). Narratives at work: The development of career identity. British Journal of Guidance \& Counselling, 40(2), 157-176. https://doi.org/10.1080/03069885.2012.665159

Moleong, J. L. (2011). Metodologi Penelitian Kualitatif. Bandung: P. Remaja Rosdakarya. 
Nazar, G., \& Heijden, B. I. J. M. van der. (2012). Career identity and its impact upon self-perceived employability among Chilean male middle-aged managers. Human Resource Development International, 15(2), 141-156. https://doi.org/10.1080/13678868.2012.664692

News Northeastern. (2014). 'Generation Z' is entrepreneurial, wants to chart its own future. Retrieved June 4, 2021, from https://news.northeastern.edu/2014/11/18/generation-z-survey/

Nurfadhilla, N. (2020). Upaya Meningkatkan Efikasi Diri Melalui Layanan Bimbingan Konseling. ENLIGHTEN: Jurnal Bimbingan Konseling Islam, 3(1), 48-59. https://doi.org/10.32505/enlighten.v3i1.1495

Porfeli, E. J., Lee, B., Vondracek, F. W., \& Weigold, I. K. (2011). A multi-dimensional measure of vocational identity status. Journal of Adolescence, 34(5), 853-871. https://doi.org/10.1016/j.adolescence.2011.02.001

Roman, L. A. (2014). Using social media to Enhance Career Development Opportunities for Health Promotion Professionals. Health Promotion Practice, 15(4), 471-475. https://doi.org/10.1177/1524839914535213

Sampson, J. P., Kettunen, J., \& Vuorinen, R. (2020). The role of practitioners in helping persons make effective use of information and communication technology in career interventions. International Journal for Educational and Vocational Guidance, 20(1), 191-208. https://doi.org/10.1007/s10775019-09399-y

Santoso, D. B. (2013). Dasar-dasar Bimbingan dan Konseling. Malang: Universitas Negeri Malang.

Sonnert, G. (2009). Parents Who Influence Their Children to Become Scientists: Effects of Gender and Parental Education. Social Studies of Science, 39(6), 927-941. https://doi.org/10.1177/0306312709335843

Stringer, K. J., \& Kerpelman, J. L. (2010). Career Identity Development in College Students: Decision Making, Parental Support, and Work Experience. Identity, 10(3), 181-200. https://doi.org/10.1080/15283488.2010.496102

Sulistyowati, M., \& Widyastuti, I. (2017). Model Konseptual Faktor Yang Mempengaruhi Keputusan Berwirausaha (Pendekatan Role Model Theory). ProBank, 2(1), 25-38. https://doi.org/10.36587/probank.v2i1.129

Tsang, S. K. M., Hui, E. K. P., \& Law, B. C. M. (2012). Positive Identity as a Positive Youth Development Construct: A Conceptual Review. The Scientific World Journal, 2012. https://doi.org/10.1100/2012/529691

Vignoli, E. (2015). Career indecision and career exploration among older French adolescents: The specific role of general trait anxiety and future school and career anxiety. Journal of Vocational Behavior, 89, 182-191. https://doi.org/10.1016/j.jvb.2015.06.005

Weber, K., \& Ladkin, A. (2011). Career Identity and its Relation to Career Anchors and Career Satisfaction: The Case of Convention and Exhibition Industry Professionals in Asia. Asia Pacific Journal of Tourism Research, 16(2), 167-182. https://doi.org/10.1080/10941665.2011.556339

$\mathrm{Xu}, \mathrm{H} .$, \& Lee, J. C.-K. (2019). Exploring the Contextual Influences on Adolescent Career Identity Formation: A Qualitative Study of Hong Kong Secondary Students. Journal of Career Development, 46(3), 219-234. https://doi.org/10.1177/0894845317737380

Zamroni, E. (2016). Urgensi Career Decision Making Skills Dalam Penentuan Arah Peminatan Peserta Didik. Jurnal Konseling Gusjigang, 2(2). https://doi.org/10.24176/jkg.v2i2.700

Article Information (Supplementary)

$\begin{array}{ll} & \begin{array}{l}\text { Conflict of Interest Disclosures: } \\ \text { The authors declare that they have no significant competing } \\ \text { financial, professional or personal interests that might have } \\ \text { influenced the performance or presentation of the work } \\ \text { described in this manuscript. }\end{array} \\ \text { Copyrights Holder: }<\text { laila }><2021> & \begin{array}{l}\text { First Publication Right: BISMA The Journal of } \\ \text { Counseling }\end{array} \\ \text { https://doi.org/10.xxxx/xxxxx } & \end{array}$

Word Count: 